\title{
Past Is Another Resource: Remembering the 70th Anniversary of the Victory Day on LiveJournal
}

\author{
Mykola Makhortykh, ${ }^{1 *}$ Yehor Lyebyedyev, ${ }^{2}$ and Daniel Kravtsov ${ }^{3}$ \\ ${ }^{1}$ Department of Slavonic Studies and Cultures, University of Amsterdam, Amsterdam, The Netherlands, ${ }^{2}$ Newfire Partners, \\ Lviv, Ukraine, and ${ }^{3}$ RTB-Media, San Francisco, California, USA \\ ${ }^{\star}$ Corresponding author. Email: makhortykhn@yahoo.com
}

\begin{abstract}
In our article we examine changes experienced by media and memory systems in Russia since the beginning of the Ukraine crisis. Using as an example a popular Russian blogging platform, LiveJournal, we scrutinize how the digital practices related to commemoration of the 70th anniversary of the Soviet victory over Nazi Germany are influenced by the growing instrumentalization of Second World War memory for media propaganda and manipulation. Using topic modeling to analyze a large set of data on Russian users' interactions with the platform, we examine how hegemonic and alternative interpretations of the Second World War interact on LiveJournal and how their interactions are influenced by the growing antagonism between Russia and the West. Our findings suggest that LiveJournal constitutes a fractured memory system, which is characterized by uneven representation of Second World War experiences and the growing influence of pro-government actors promoting hegemonic war narratives. However, our observations also show that instrumentalization of the past in the context of the Ukraine crisis does not necessarily interfere with digital practices of Second World War commemoration with the latter remaining unaffected by the events in Ukraine.
\end{abstract}

Keywords: digital media; memory; propaganda; Second World War; Russia

\section{Introduction}

The Ukraine crisis, which started in 2013 with anti-government protests in Kyiv, followed by the ousting of pro-Russian President Yanukovych and the annexation of Crimea by Russia in March 2014, has signified a profound change in the Russian media landscape. The development of the crisis, in particular the ongoing conflict in Eastern Ukraine between the Ukrainian government and pro-Russian insurgents, led to the rise of nationalist propaganda and anti-Western rhetoric in the Russian public sphere. Together with the unprecedented level of state-sponsored cynicism toward the democratic role of mass media (Roudakova 2017), these transformations have led to increased instrumentalization and militarization of traditional and online media in Russia.

Under these circumstances, the line between predominantly state-controlled mainstream media outlets and "more independent, international, and oppositional" (Etling et al. 2010) online platforms in the post-2014 period became a blurry one. Both analogue and digital media turned to be susceptible to propaganda and manipulation by pro- and anti-Kremlin actors and, instead of providing more nuanced views on domestic and international affairs, online outlets became fertile grounds for producing fake news and nurturing polarized views (Makhortykh and Lyebyedyev 2015; Gruzd and Tsyganova 2015; Zhdanova and Orlova 2017).

(C) Association for the Study of Nationalities 2020. This is an Open Access article, distributed under the terms of the Creative Commons Attribution licence (http://creativecommons.org/licenses/by/4.0/), which permits unrestricted re-use, distribution, and reproduction in any medium, provided the original work is properly cited. 
In this article, we discuss the impact of these changes on the media and memory landscape in Russia by examining interactions between cultural memory of the Second World War and the Russian blogosphere after 2014. A number of works (Zvereva 2011; Rutten, Fedor, and Zvereva 2013; Gaufman 2015; Bernstein 2016) note particular interconnectedness between processes of cultural remembrance and media digitalization in Russia, where online spaces form "a pivotal discursive territory" (Rutten and Zvereva 2013,2) for interacting with the region's turbulent past and present. For this reason, the instrumental (ab)uses of the Russian media landscape in the course of the Ukraine crisis often involve appropriation of traumatic memories of past conflicts which serve as integral modulators for discursive construction of (in)security in the region (Gaufman 2015, 2017; Makhortykh 2018). By using a cultural remembrance lens to scrutinize changes in the Russian media landscape, we investigate the influence of these alterations on mnemonic functions of the regional media and explore dynamic interactions between changing media and memory systems in Russia.

In order to fulfill these goals, we examine digital activity on the major Russian blogosphere platform, LiveJournal, around the 2015 Victory Day, which marked the 70th anniversary of the Soviet victory over Nazi Germany. Our choice of LiveJournal as a case platform is attributed for three major reasons. First, during the period of study, LiveJournal constituted the largest blogging service in Russia as well as the fourth most popular social media platform among Russian users (Frolova 2015). Second, LiveJournal is characterized by a distinct set of communicative practices which distinguish it from other social networking sites like Vkontakte or Facebook (Kuntsman 2010; Kulyk 2013) and have significant impact on the way the past is narrated (Trubina 2010; Abramov 2011; Kukulin 2013), Third, LiveJournal is recognized as an important platform for political communication in Russia (Etling et al. 2010; Asmolov 2012; Kluyeva 2016) that is used both by pro-government and opposition actors to advance their political agendas.

The Victory Day is a central element of cultural remembrance of the Second World War in the post-socialist space (Gudkov 2005; Trubina 2010; Bernstein 2016). For this reason, the jubilee event in 2015 attracted significant coverage both in traditional and online media, which also used this occasion to reinforce their representation and interpretation of the Ukraine crisis. Using a large set of digital data collected from LiveJournal, we discuss the following questions: How was the jubilee of Soviet victory discussed on digital media and in which ways were these discussions affected by evolving memory regimes in the region? How did hegemonic and alternative interpretations of the Second World War interact on LiveJournal and in which ways were these interpretations influenced by the growing antagonism between the West and Russia? And, finally, what are the implications of the ongoing transformations of regional media landscape for war remembrance in Russia?

To answer these questions, we start by scrutinizing the changes experienced by media and memory systems in Russia since the beginning of the Ukraine crisis; while doing so, we specifically examine the role of LiveJournal in the context of political communication and cultural remembrance in the region. Following the examination of the platform's role in the above-mentioned contexts, we present our methodological approach and describe how we used topic modeling techniques to process and analyze the large set of Victory Day-related content from LiveJournal. Then, we discuss our findings, starting with general patterns of representing the 70th anniversary of the Soviet victory on LiveJournal, followed by the investigation of its use by pro- and anti-Kremlin actors in the context of the Ukraine crisis. We conclude by discussing the impact of the growing instrumentalization of digital media in the context of the Ukraine crisis on the memory and media systems in Russia.

\section{Russian Blogosphere as Part of a Changing Media System}

The Russian blogosphere is constituted by a vast collection of digital platforms which originate both in Russia (e.g., Diary.ru) and outside of it (e.g., Twitter). These platforms host communities of Russophone users who run individual and collective blogs; the purposes of these blogs vary from personal diaries to news feeds and from thematic communities to advertisement groups. The 
functions of the Russian blogosphere are not limited to entertainment only: in the context of the Russian public sphere, where ordinary citizens often have limited capabilities to shape public agendas, it also serves as a major outlet for social and cultural self-expression (Kukulin 2013, 112). In this way, the Russian blogosphere allows internet users to participate in the discussion of current political developments, including the Ukraine crisis (Suslov 2014), and share their opinions on the matters of cultural remembrance such as Second World War commemoration in Russia (Trubina 2010).

In this article, we examine changes in the Russian blogosphere by focusing on the LiveJournal platform, which is an integral component of its ecosystem. LiveJournal is a popular blogging service which was established in 1999 by Brad Fitzpatrick. Soon after its establishment, LiveJournal became popular among Russophone users and in the following years turned into the most popular blogging platform in Russia (Yandex 2006). In 2007, LiveJournal was acquired by the Russian company, SUP Media, and in 2016 the platform's US-based servers were relocated to Russia. In 2017, LiveJournal changed its terms of service to comply with the requirements of the Russian legislation, which caused a massive withdrawal of its users. However, despite the decrease in its audience size, LiveJournal remains the 16th most popular web resource in Russia (Alexa 2018) and the country's most popular blogging service, serving as an important medium of political communication and cultural remembrance.

\section{Live Journal and Political Communication}

LiveJournal occupies a special place in the Russian blogosphere: it is one of the major blogging platforms which is also engaged extensively in the formation of political agendas in Russia (Etling et al. 2010). Kuntsman $(2010,302)$ notes that unlike other blogging services, LiveJournal is a welldeveloped discussion platform which facilitates debates through its bulletin-like structure and vibrant social environment. The platform's potential for political self-expression was further enhanced by the relative lack of government control on digital media in the 2000s, leading to LiveJournal being used as a watchdog on Russian elites and the government (Etling et al. 2010, 33). While pro-government bloggers were also present on the platform, their visibility during that time was not significant.

In the period of the massive anti-government protests in Russia in 2011-2012, LiveJournal together with Facebook (Bodrunova and Litvinenko 2013) served as a major information outlet for the Russian political opposition. Koltsova and Shcherbak $(2015,1729)$ explain the phenomenon of "the overwhelming opposition of the blogosphere" both by the audience makeup (i.e., the Russian middle class requesting a new political agenda) and the platform's accessibility (i.e., the lack of government censorship). Under these conditions, LiveJournal was extensively used not only as a space for expressing societal discontent with the election fraud, but also as a means of public mobilization and protest coordination by the opposition forces (Asmolov 2012; Kluyeva 2016).

In the period following the beginning of the Putin's third presidential term and the emergence of the Ukraine crisis, the position of the Russian blogosphere has changed significantly. The introduction of the large number of legal constraints (e.g., mandatory identity verification for social media users, legal persecution for producing and sharing extremist content, and enforcement of the information security law) has curtailed possibilities for the platform's use as a means of online participation and mobilization by opposition actors (Kluyeva 2016; Denisova 2017). Furthermore, the visibility of the pro-government actors in the Russian digital spaces significantly increased at the time of the Crimea's annexation and the subsequent conflict in Eastern Ukraine, leading to the use of these spaces as part of heated information warfare both inside and outside Russia (Gaufman 2015; Makhortykh 2018).

The impact of these changes on LiveJournal until now remains an open question. The majority of earlier studies on the post-2014 media landscape in Russia have focused on the changing role of social media platforms such as Facebook (Mejias and Vokuev 2017) or VKontakte (Gaufman 2017) whereas the alterations experienced by the Russian blogosphere, in particular LiveJournal, remain 
under-investigated. By scrutinizing the platform's use in the context of the highly politicized media/ memory event (i.e., the Victory Day), we attempt to estimate the visibility of the pro-government and opposition actors across LiveJournal and access the platform's potential as a means of political communication in the changing media landscape in Russia.

\section{Live Journal and Cultural Remembrance}

Another aspect of LiveJournal, which contributes to our interest in its place in Russia's media landscape, is the platform's role as a medium of cultural remembrance. Through its design, LiveJournal enables the establishment of "a new hybrid form of private and public memory" (Garde-Hansen, Hoskins, and Reading 2009, 6), which turns internet users into "prosumers" (Tofler 1980) of memory content. The low costs of production and circulation of digital memory products facilitate the preservation of individual memorabilia (e.g., by transforming digital blogs into individual archives/museums) and influence the evolution of public remembrance practices (e.g., by enabling the collaborative production of alternative historical narratives online). The latter quality is particularly important in the case of fractured memory regimes, which are characterized by the instrumentalization of the past by political actors, who try to monopolize control over public memory practices and use them to legitimize current political decisions (Bernhard and Kubik 2014, 17).

Under the condition of the intense politicization of the past, digital platforms such as LiveJournal have the potential to pluralize cultural remembrance, particularly in the case of hegemonic memory discourses promoting national unity and cohesion, which is often the case of war remembrance. In her study of Second World War memory on LiveJournal, Trubina (2010) demonstrates how the platform sustains a more inclusive understanding of the past by enabling the emergence of memory frameworks different from the traditional nation-centered perspectives on the war. A similar assessment is made by Morenkova (2011), who notes the pluralizing influence of LiveJournal on the collective remembrance through the promotion of widely diverging historical visions on the Soviet period in Russia.

At the same time, the pluralization of remembrance does not nullify the significant online presence of mainstream and state-sponsored interpretations, which are often enhanced by the popular feelings of nostalgia (Bernstein 2016). Because of this reason, LiveJournal frequently turns into the arena of discursive online combats between adherents of different interpretations of the past, also known as web wars (Rutten, Fedor, and Zvereva 2013). Kukulin (2013) notes that these discursive confrontations often involve domestic and foreign actors, who compete for promoting their preferred version of history. Similarly, Kuntsman $(2010,311)$ demonstrates how LiveJournal debates can contribute to the circulation of conflicted views on the past and present military conflicts by reinforcing racial, national, and colonial formations among web users.

The beginning of the Ukraine crisis intensified web wars in the Russian blogosphere as pro- and anti-Kremlin actors employed cultural memories, especially of the Second World War, for representing and interpreting the events in Ukraine (Gaufman 2015; Makhortykh 2018). The major goal of such manipulative uses of memory, as Gaufman (2015) notes, usually was to stigmatize and dehumanize the opposing side using emotionally charged memory tropes such as "Nazi" or "fascist junta." The implications that this instrumentalist approach toward Second World War memory has for LiveJournal's role as a medium of cultural remembrance are not yet clear. In order to estimate these implications, we attempted to go beyond the simple mapping of instrumentalist (ab)uses of the past at the time of Ukraine crisis through the platform and, instead, consider their long-term impact on Second World War remembrance on the Russian blogosphere.

\section{Victory Day as Part of a Changing Memory System}

From its beginning, the official observance of the Soviet victory over Nazism was closely related to identity-building and propaganda. Introduced in 1945 with a grand military parade in Moscow, the 
Victory Day was massively celebrated in 1946, when numerous manifestations, public strollings, and street performances took place. The next year, however, the Victory Day was demoted from a state holiday to a regular working day. This decision was caused by Stalin's desire to focus public attention on the economic reconstruction in the Soviet Union and the brewing Cold War (Tumarkin 1994, 103); furthermore, it diverted public attention from the Soviet military leaders, whose popularity could become a threat for Stalin's personal power (Overy 1998, 281).

The Victory Day started to regain its official status in the 1950s, when the representation of the Soviet victory became part of the de-Stalinization campaign led by Khrushchev. In his 1956 speech, Khrushchev condemned Stalin's attempts to monopolize the Soviet victory over Nazi Germany and, instead, emphasized the leading role of the Communist Party supported by tens of millions of Soviet people (Tumarkin 1994, 109). Despite these changes in the official rhetoric, the Victory Day was restored to its public holiday status only in 1965, when Brezhnev came to power in the Soviet Union. This change was integral for the formalization of the Great Patriotic War myth, which became an important consolidation mechanism for the Soviet society and led to the establishment of new public symbols (e.g., the Eternal flame) and practices (e.g., the jubilee military parades in Moscow) of remembering the Soviet victory.

With the beginning of the Perestroika, the growing criticism of the Communist party was accompanied by the gradual revision of the Soviet narrative of the Second World War. Initiated by Gorbachev as part of his attempts to reform the Soviet system, this process resulted in the change of official attitude toward the Victory Day after the dissolution of the Soviet Union. In his attempts to dismantle symbols of the Communist party's success, Yeltsin abstained from massive celebrations of the Victory Day in 1992 (Bernstein 2016, 426). In the next years, however, the observance of the Victory Day was resumed as the Yeltsin government tried to establish new commemorative practices (e.g., the use of Russian tricolor along the red Soviet flag during the parades and the introduction of the Day of Memory and Sorrow on June 22) that could consolidate the Russian society, while distantiating from the Soviet traditions (Malinova 2017).

The beginning of Putin's first presidential term in 2000 has led to significant changes in Second World War commemoration. Like Brezhnev a few decades earlier, Putin employed the narrative of the Soviet victory for national consolidation. This process involved not only the invention of new commemorative rituals such as the use of the Saint George ribbon (Kolstø 2016), but also the instigation of restrictions on Second World War research in Russia and the introduction of the uniformed perspective on teaching about the war (Bernstein 2016). Through these means, Russian authorities consolidated their monopoly on public remembrance of the Second World War. This monopoly was further reinforced by the adoption of memory legislation in 2014 which made the dissemination of false information about the Soviet Union's actions during the war a criminal offence (Koposov 2017).

After the beginning of the Ukraine crisis, the Victory Day became instrumentalized by the Russian authorities in the context of the foreign politics. Not only it was reformulated with a more nationalistic rhetoric and used as a conceptual framework to explain and interpret the crisis in Ukraine (Siddi 2017), but also became increasingly used for propagating the state-sponsored ideas of the Russian World (Gaufman 2017). The latter approach was exemplified in the Immortal Regiment movement that started as a grassroots campaign in 2012, but in the later years was monopolized by the state and turned into a means of Russian soft power (Fedor 2017).

The increasing instrumentalization of Second World War memory in the context of the Ukraine crisis had implications for commemoration of the 70th anniversary of the Victory Day. In Ukraine, the deterioration of relations with Russia resulted in the profound changes in the public rhetoric in relation to the Victory Day, including the switch of major commemorative events from May 9 to May 8 (i.e., European Remembrance Day) and the adoption of a novel symbol of red-and-black poppies together with intense criticism of both Nazi and Stalinist regimes (Khrebtan-Hörhager 2016). In contrast to Ukraine's mnemonic Westernization, in Russia the 70th anniversary of the Soviet victory turned into an anti-Western "show of defiance" (Edele 2017, 105) which combined 
accusations of Western powers for being historically responsible for the beginning of the Second World War with unprecedented demonstrations of military prowess and attempts to justify the Molotov-Ribbentrop pact as part of the larger process of "re-Stalinization" (Khapaeva 2016).

Under these conditions, memory of the Soviet victory became a weapon in the rhetorical conflicts around the Ukraine crisis (Kupfer and de Waal 2014). It was used to represent and interpret specific episodes of the crisis: for instance, the defence of the Donetsk airport which was compared in Ukraine with the battle for Stalingrad (Beckhusen 2015) both in terms of Ukrainian soldiers' resilience and of both episodes being viewed as integral steps for the eventual victory in the war. At the same time, memories of the Soviet victory were used to emphasize ideological differences between opposing sides (e.g., by framing Ukrainian soldiers as Nazi successors, who return after the crushing defeat in 1945 to exterminate the Donbas population (Sazonov, Müür, and Holger 2016).

\section{Methodology}

For implementing our research, we used data provided by RTB Media, a US-based data analytics company specializing in online advertisement campaigns. RTB Media aggregated data on browsing history of the large sample of web users from Russia (i.e., served by Russian internet providers) through cookies. The users had to provide their consent for the data to be collected, and then the aggregated data were anonymized to protect users' privacy. From all the data collected by the company between May 4 and 11, we acquired data about users' visits to LiveJournal. The resulting data set consisted of 12,562 unique posts, which were visited by RTB-Media users. Then, we extracted contents of these LiveJournal posts and standardized (i.e., tokenized, stemmed, and stripped of stopwords) them with the help of Python NLTK package.

After standardizing our data set of LiveJournal posts visited between May 4 and 11, 2015, we selected posts relevant for the Victory Day commemoration. For this purpose, we employed Java Mallet package which is used for topic modeling (i.e., detection of thematic clusters by identifying terms which occur together within a given text). Like earlier studies using topic modeling for processing large volumes of LiveJournal data (Koltsova and Koltcov 2013; Bodrunova et al. 2013), we used latent Dirichlet allocation (LDA) ${ }^{1}$ for identifying distinct topics present in our dataset.

Koltsova and Koltcov (2013) note that the process of determining the optimal number of topics is a particularly challenging aspect of topic modelling using LDA. To solve this task, we adopted the approach used by Bodrunova et al. (2013), a series of experiments with the different number of topics for LDA. After comparing these experiments' results by visualizing their hierarchical clustering, we identified that 80 is the optimal number of topics for our data set. The close reading of the topics resulting from this model by three coders (i.e., paper's authors) allowed us to discover eight thematic clusters relevant for Second World War remembrance: these clusters are shown in Table 1 and include terms related to military activities (e.g., division, tank, defense), war commemoration (parade, Soviet, star, St. George), and Second World War history (Stalin, Hitler, Auschwitz, Reichstag).

Following the detection of topics specific for the Second World War, we used these topics to identify LiveJournal posts dealing specifically with the subject of our research, the Second World War and Victory Day commemoration. Using Mallet, we selected all posts which included terms from at least two thematic clusters showed in Table 1 . The resulting data set consisted of 2,463 LiveJournal posts related specifically to the Second World War. Based on this filtered data set, we trained a series of models using LDA to identify distinct topics present in the filtered sample of Second World War-related posts. Again, following the approach by Bodrunova et al. (2013), we ran series of experiments with the different number of models in the range from 100 to 400 topics. Then, we used hierarchical clustering for comparing experiments' results and chose a model with 300 topics which was identified by coders as the one with the highest degree of topic interpretability. We then grouped together topics which occurred at least in 10 percent of the filtered data set using 
Table 1. Second World War Thematic Clusters (Nonfiltered Sample).

\begin{tabular}{|c|c|c|}
\hline$\#$ & Frequency & Terms \\
\hline 9 & 0.05904 & $\begin{array}{c}\text { войн герман немецк польш немц советск арм гитлер миров втор польск год войск ссср европ } \\
\text { солдат воен союзник франц союз французск берлин русск германск территор побед генера } \\
\text { муссолин прот красн нацистск западн тыс американск поляк посл част нацист австр англ }\end{array}$ \\
\hline 16 & 0.01713 & $\begin{array}{l}\text { советск берлин арм воен войн год союз генера войск фронт ссср велик рейхстаг друг сво воин } \\
\text { котор марша армя танков побед отечествен армянск команд полковник солдат дивиз перв армен } \\
\text { севастопол офицер армян геро стран лейтенант гвардейск танк бол гер воздушн }\end{array}$ \\
\hline 21 & 0.05786 & $\begin{array}{l}\text { войн фронт арм солдат командир немецк войск воен дивиз боев батальон противник полк танк } \\
\text { част немц ранен район оборон наш атак бойц групп офицер плен враг действ бригад крепост } \\
\text { наступлен рот приказ потер сил лейтенант стрелков операц танков позиц штаб }\end{array}$ \\
\hline 40 & 0.03538 & $\begin{array}{l}\text { орд год войн отечествен медал наград красн орден лент георгиевск побед велик арм советск звезд } \\
\text { степен воен геро слав награжд боев крест зван гвардейск флаг кавалер сержант генера заслуг } \\
\text { символ подвиг меда знак награжден союз георг знамен гвард ссср котор }\end{array}$ \\
\hline 52 & 0.14081 & $\begin{array}{l}\text { побед парад войн ден праздник велик наш дед люд ветеран отечествен москв год красн народ полк } \\
\text { лет площад ленточк город памя георгиевск воен сегодн дня бессмертн символ ветера мероприят } \\
\text { истор акц памят флаг геро цвет стран сво лент солдат праздничн }\end{array}$ \\
\hline 53 & 0.01854 & $\begin{array}{l}\text { лагер ленинград военноплен плен концлагер немц советск лес партиза мест котор войн отряд } \\
\text { освенц немецк люд блокад расстрел узник оруж съемк офицер расстреля город деревн кантар } \\
\text { част дел партизанск дет дом велик заключен барак бежа полицейск октябр польск сара катрюк }\end{array}$ \\
\hline 54 & 0.04331 & $\begin{array}{l}\text { сталин советск ссср войн воен ленин москв союз год верховн красн начальник совет фронт велик } \\
\text { ставк товарищ руководств парт работ войск сил коммунист московск государствен управлен } \\
\text { отечествен сталинск вопрос член дел действ главнокоманд власт нквд час политическ штаб } \\
\text { большевик решен }\end{array}$ \\
\hline 62 & 0.15256 & $\begin{array}{l}\text { русск росс народ сво стран котор наш власт мир государств люд войн российск истор тольк } \\
\text { советск национальн имен фашизм прав прот ссср политик год даж счита пропаганд враг называ } \\
\text { свобод обществ одн населен нац украин себ запад родин отношен стал }\end{array}$ \\
\hline
\end{tabular}

hierarchical clustering. The distance between topics was measured using the Jaccard similarity index; the resulting set of clusters consisted of 11 cluster groups which are presented in data set 1 .

\section{Findings \\ General Representation}

We started our analysis by examining general features of Second World War content accessed by users from our sample. For this purpose, we examined eight thematic clusters related to the Second World War in the entire data set (i.e., 12,562 posts). By examining these eight clusters, we identified specific topics associated with the Second World War in our data set and determined which of these topics were more visible than the others around the 70th anniversary of the Victory Day.

Table 1 points out the significant presence of two thematic clusters: the first (\#52) focused on official memorial practices (0.14081) and the second (\#62) dealt with nationalistic propaganda (0.15256). The first cluster included both general terms associated with the Victory Day celebration (e.g., veterans, memory, flags, symbols) and the ones referring toward specific memory practices (e.g., immortal, George, band). In the latter case, the terms referred exclusively to the practices supported by the Russian government such as the Immortal regiment and the St. George band.

\section{Table 1. Second World War Thematic Clusters (Non-Filtered Sample)}

The second significant cluster (\#62) combined terms applicable both to the Second World War and the current geopolitical situation. The cluster included references toward collective identities-both 
in Russia (e.g., Russian, Soviet, USSR, people) and outside of it (e.g., West, Ukraine)_as well as terms related to political propaganda (Motherland, Nazi, fascism). The examination of this cluster highlighted several points: firstly, among potential geopolitical opponents only Ukraine was singled out, whereas other countries were referred collectively as the West. Secondly, the cluster did not mention countries which were fighting against the Soviet Union during the Second World War (e.g., Germany) or symbols associated with the Soviet victory over these countries (e.g., Reichstag); instead, the cluster employed general references such as Nazi or fascists.

Besides two clusters focused on state-sponsored practices in relation to Second World War remembrance (i.e., official commemoration rituals and the use of cultural memory as a means of propaganda), we identified clusters related to the international context of the Second World War (\#9) and combat actions in the course of the war (\#21) together with the role of the Communist party and Stalin (\#54) and Soviet military rewards (\#40). The visibility of these clusters, however, was significantly less noticeable which can be interpreted as an indicator of lesser interest toward Second World War history-as well as native Soviet memory practices-compared with the current state of remembering the war as well as references toward it in the context of anti-Western and especially anti-Ukraine rhetoric.

Another aspect of Second World War representation on LiveJournal was related to the limited visibility of traumatic war experiences. Cluster \#53 was the only one including terms such as concentration camps, blockade, and mass shootings as well as references toward specific places of mass murder (e.g., Auschwitz). These terms not only co-occurred relatively rarely (0.01854), but they also did not appear in other clusters, thus making an isolated group. Similarly, cluster \#16 included terms which were rarely used (0.01713). However, in the case of these terms, which mostly concerned the seizure of Berlin by the Red Army (e.g., Berlin, Reichstag, USSR, general, tanks), the lack of visibility can be attributed not to the triumph-centered nature of celebrations, but to the cluster's focus on events which contradict the idea of close Russian-German relations, which is an important concept in Russian current foreign politics.

\section{Political Representation}

Following the examination of general patterns of Second World War representation, we scrutinized the visibility of pro-government and opposition narratives on LiveJournal. Before the Ukraine crisis, LiveJournal was often viewed as a platform used by the Russian opposition to produce and disseminate narratives alternative to the ones propagated by the mainstream media (Bodrunova and Litvinenko 2013; Kluyeva 2016). Our observations from the previous section indicated that Kremlin-driven memory initiatives together with the use of cultural memories for political propaganda were the most visible topics in our data set. However, we still did not know if the high visibility of these subjects meant that LiveJournal users criticized these practices or actually supported them through their posts.

In order to answer this question, we used the filtered sample (i.e., the one made of posts specifically related to the Second World War) and examined groups of thematic clusters shown in data set 1. Our analysis indicated that the majority of cluster groups-seven out of eleven-showed political sentiment which was not easily attributed to a pro- or anti-Kremlin stance. Examples of such cluster groups included cluster group \#2 which combined topics with rather general terms (e.g., cluster \#134 -society, real, imagine, times) and cluster group \#10 focused on historical aspects of the Second World War (e.g., cluster \#54-army, division, tanks, Germans, liberation).

Among all cluster groups, only the smallest group (\#8) was predominantly critical toward Kremlin. This group was made of two thematic clusters and included negative reactions toward the Russian foreign policy, in particular the Crimea's annexation (\#299-Putin, dictator, Putler, Crimea, victims) together with criticism of the official memory practices viewed as part of Kremlin's soft power, in particular the use of St. George's ribbon (\#54-George, ribbon, symbol, no, relation, poppy). 
By contrast, three cluster groups were made of LiveJournal posts primarily supporting the Russian government. Cluster group \#11 was made of posts dealing with geopolitical issues such as criticism of Western countries (\#42-US, England, Anglo-Saxon, occupation, Iraq and \#65-US, Europe, Russia, sanctions, geopolitical, conflict), appropriation of Second World War memory for stigmatizing Ukraine (\#113-Ukraine, Banderites, Maidan, Nazi, OUN, Donbass, aggression), and praising Russian people for their victory in the Second World War (\#86-our, victory, heroes, veterans, victors). Two other cluster groups (\#4 and \#5) were focused on the Victory Day celebration in Russia (\#270-veterans, thank, greetings, respect, holy) and supported official memory practices (\#186-parade, Armata, greetings, order, triumphal and \#88-immortal, regiment, relatives, thousands, portraits).

A separate category of cluster groups incorporated posts with anti-Ukrainian sentiment which did not express support to the Kremlin politics. Cluster group \# 1 consisted of posts criticizing and making fun of patriotic feelings among Ukrainians (\#98-patriotism, Europe, victims, misery, tragedy and \#184-patriots, rot, senseless, spit, duty). Cluster group \#9 was centered around the conflict in Eastern Ukraine and included posts stigmatizing Ukrainians (\#28-fascists, Banderites, horror, terror, shame), depicting war suffering (\#147-war, tears, house, horrible, photos) and describing the celebration of the Victory Day in the Donetsk People's Republic (\#7-people, city, center, photographer, joy).

The examination of cluster groups pointed out the increased presence of pro-government actors in the Russian blogosphere together with the limited visibility of Russian opposition bloggers. The anti-Kremlin narratives were more actively promoted by pro-Ukrainian actors, who specifically criticized Russia's involvement in the Ukraine crisis. Such a criticism, however, was overshadowed by the notable support of the Russian government's politics—both domestic (i.e., official memory politics with a single exception of the St. George's Ribbon which remains a controversial element of public remembrance) and foreign one (i.e., anti-Western and especially anti-Ukraine course). Together with widespread anti-Ukrainian sentiment, these observations suggest that LiveJournal was increasingly used for channeling pro-Kremlin sentiment, while occasionally turning into an international battlefield between pro-Russian and pro-Ukrainian actors.

\section{Cultural Remembrance}

In the last section of our study, we examined the role of LiveJournal in the framework of cultural remembrance in Russia. We were particularly interested in the impact of conspicuous instrumentalization of Second World War memory during the Ukraine crisis-also confirmed by our observations on the general visibility of specific aspects of the Soviet victory on LiveJournal-on the platform's use in the context of the Victory Day celebration. In order to investigate this question, we again used the filtered sample of 2,463 posts related specifically to the Second World War.

Our analysis identified four distinct cluster group sets based on the presence of memory-related topics. The first of these sets-cluster groups \#5 and \#4-was specifically focused on official commemoration practices related to the Victory Day. The topics included in this set varied from the general aspects of public commemoration (\#199-day, celebration, memory, victors, mourning, jubilee and \#132-activities, victory, celebration, monument, concert) to more specific practices such as expressions of gratitude to Soviet veterans (\#270-veterans, thank, greetings, respect, holy), the Immortal Regiment campaign (\#88-immortal, regiment, relatives, thousands, portraits) and the military parade in Moscow (\#186-parade, Armata, greetings, order, triumphal). The prominence of these subjects aligns with the observations produced by the interview-based study by Emelianova and Mishanina (2014), who demonstrated that for different age groups of Russian population official memory practices remain the key aspect of the Victory Day commemoration.

More traumatic aspects of the Second World War were referenced in the second set represented by cluster groups \#6 and \#9. Thematic cluster \#47 in cluster group \#6 was dealing with war-time imprisonment and mass murders (e.g., imprisonment, camp, fascists, murder, partisans), whereas 
cluster \#60 in cluster group \#9 referred to post-war trauma (e.g., children, postwar, orphans, death, hospital, teens). The absence of references to these traumatic experiences in other clusters suggests that only a small subset of isolated LiveJournal posts concerned these distressing elements of Second World War memory.

Similar observations were produced by Golovashina, Linchenko, and Anikin (2017) in their qualitative analysis of LiveJournal content produced around the Victory Day which points to the limited presence of traumatic aspects of the Second World War, particularly occupation, imprisonment and concentration camps. Such a limited visibility contrasted sharply with the wide presence of official commemorative practices glorifying the Soviet victory and seems contradictory to pre-2014 assessments of the Russian blogosphere as a possible platform for integrating the official narrative of the war with more nuanced and cosmopolitan views on the past (Trubina 2010).

The third set was represented by cluster group \#10, made of topics which concerned the history of the Second World War. The group incorporated topics discussing Soviet Union's participation in the war (\#167-war, front, reward, red, star, sergeant, liberation and \#176-Soviet, army, hero, liberation, struggle, fascists, defeat) and specifically military confrontations with German forces (\#50-division, German, operation, city, combat, June). The cluster group also included a cluster which referred to the actions of the Allies (\#1-war, million, ally, Nazi, holocaust, Hiroshima); this cluster was the only one mentioning the Holocaust together with Hiroshima bombardment. The particular visibility of the latter subjects, in particular of Allies' involvement in potential war crimes, as contrasted by the emphasis on the non-equivocal heroism of Soviet soldiers, can be attributed to the growing anti-Western sentiments in Kremlin foreign politics, which also affect the Victory Day commemoration (Edele 2017).

Finally, the fourth set consisted of three cluster groups-\#8, \#9, and \#11-which referred to the Second World War memory in the context of the Ukraine crisis. A smaller cluster group-\#8included criticism of the Kremlin memory politics (\#54-George, ribbon, symbol, no, relation, poppy) and employed selective memory tropes such as Putler (Putin + Hitler) to draw parallels between Russia and Nazi Germany in the context of the Russia's intervention in the Ukraine crisis (\#299-Putin, dictator, Putler, Crimea, victims). By contrast, cluster group \#9 included posts which instrumentalized Second World War memory to present the conflict in Eastern Ukraine as a direct continuation of the Second World War by framing Ukrainians as successors of Nazi Germany (\#28-fascists, Banderites, horror, terror, sin), depicting war suffering (\#147—war, tears, house, horrible, photos) and describing the celebration of the Victory Day by the pro-Russian insurgents (\#7-people, city, center, photographer, joy). The same forms of memory instrumentalization were observed also for other online media platforms during the Ukraine crisis-for example, Vkontakte (Gaufman 2015) and Twitter (Makhortykh 2018).

The last group in the fourth set, cluster group \#11, included a variety of posts using cultural memories for representing the Ukraine crisis. The majority of these posts were focused on military conflicts, in particular the Second World War; examples included references to the heroism of soldiers and protection of the Motherland (\#86-our, victory, heroes, veterans, victors) as well as the aggressiveness of occupants (cluster \#289 referred to Soviet occupants (Soviet, enemy, occupants, eastern, border), whereas cluster \#42 presented Western countries as occupants (US, England, Anglo-Saxon, occupation, Iraq) and collaborators (i.e., Ukrainians in the case of cluster \#113 [Ukraine, Banderites, Maidan, Nazi, OUN, Donbass, aggression]). Other topics in the cluster group referred to the geopolitical confrontation between the West and Russia (\#65-US, Europe, Russia, sanctions, geopolitical, conflict).

Such a strong focus on instrumentalization of Second World War memory in the context of the Ukraine crisis contrasts with the seeming absence of references toward family memories of the war, despite these references being frequently noted by other more qualitative studies of digital memory practices in relation to the Victory Day (Golovashina, Linchenko, and Anikin 2017). Similarly, our analysis showed limited presence of debates about historical aspects of the Second World War, which were rather visible in the Russian blogosphere in the pre-2014 period (Zvereva 2011; Rutten, Fedor, and Zvereva 2013). 
Our observations indicated the presence of distinct categories of memory content related to the Second World War on LiveJournal; furthermore, we observed that these categories usually did not intersect with each other. Topics related to the war atrocities (e.g., the Holocaust) and military history constituted isolated clusters and usually did not appear in the context of two larger clusters which dealt with official memory practices and instrumentalization of Second World War memory. Moreover, the latter two clusters showed little intersection between each other that can suggest that LiveJournal users tended to differentiate between the instrumental use of Second World War memory during the Ukraine crisis (e.g., the use of Nazi/fascists memory tropes as a means of stigmatizing the opponents) and Second World War commemoration in the context of the Victory Day (e.g., the expression of gratitude to veterans/grandparents for their heroism). The only exception from this pattern was found in cluster \#9 which referred to the celebrations of the Victory Day in the Donetsk People's Republic.

\section{Conclusions}

In our study we examined changes experienced by digital media and cultural memory ecosystems in Russia since the beginning of the Ukraine crisis. Several studies suggest that after 2014, both ecosystems were increasingly used by the Russian authorities to mobilize public support for Kremlin's foreign politics, especially Russia's annexation of Crimea and intervention in the conflict in Eastern Ukraine. These changes are particularly visible in the context of the Victory Day, a central element of Second World War remembrance in the post-socialist space, which on the official level increasingly turns into an element of Kremlin's defiance campaign against the West (Edele 2017), whereas references toward it on digital media serve as a major rhetorical device for framing the Ukraine crisis as a matter of existential (in)security for Russia (Gaufman 2015; Makhortykh 2018).

Using LiveJournal as an example, we demonstrated how the digital practices related to commemoration of the 70th anniversary of the Soviet victory over Nazi Germany were affected by the growing instrumentalization of Second World War memory for media propaganda and manipulation. Unlike many studies looking on LiveJournal in the context of political communication and cultural remembrance in Russia, we looked not on what content was published around the Victory Day in 2015, but what content was viewed by the large sample of users from Russia. We found two major categories of LiveJournal posts viewed in relation to the Victory Day: one of them dealt with official practices commemorating the Soviet victory, whereas another was primarily dealing with appropriation of Second World War memory for the current geopolitical situation, in particular promoting anti-Western and anti-Ukrainian sentiments.

The more detailed examination of LiveJournal content visited by users around the 70th anniversary of the Soviet victory showed that efforts of pro-Kremlin actors for drawing parallels between Ukraine/the West and Nazi Germany, as well as the Ukraine crisis and the Second World War, were particularly visible. Similar instrumentalization efforts by pro-Ukrainian actors, who referred to the past to present Russia as an adversary like Nazi Germany, were also found in our sample, albeit less frequently. Together, these observations point out the significant presence of activities related to the appropriation of cultural memories of the war in the context of the Ukraine crisis. Similar to other platforms such as VKontakte (Gaufman 2015) and Twitter (Makhortykh 2018), the purpose of these activities was usually related to stigmatizing political opponents, in particular pro-Ukrainian actors, using affective memory tropes such as "Nazi" or "fascists."

Because we were able to obtain data only for the period of May 4-11, 2015, and only for LiveJournal, our study was not able to draw a comparison with Victory Day-related user activities on other platforms. We acknowledge that such a comparative approach is highly beneficial for contextualizing our findings and strongly emphasize the importance of future studies adopting it for studying instrumentalization of Second World War memory in Russia. Similarly, we recognize our study's limitations in terms of the comparison between our findings and observations from the pre-2014 period: for doing so, we had to rely on existing scholarship on digital practices related to 
the Victory Day and political communication on LiveJournal. While many of these studies focus primarily on the content (i.e., what kind of LiveJournal posts are published) and not its consumption (i.e., what kind of LiveJournal posts are actually viewed), the observations produced by them still allow us to make rough estimates of visibility of different categories of actors in the pre-2014 period. Based on these estimates, our findings indicate the significantly higher visibility of actors promoting pro-Kremlin agendas through the Russian blogosphere since the beginning of the Ukraine crisis.

The increased presence of pro-government actors is contrasted by the lesser visibility of Russian opposition actors; instead, we observed the major presence of pro-Ukrainian actors who criticized Russian authorities for their involvement in the Ukraine crisis. Under these conditions, the earlier role of LiveJournal as the digital stronghold of the Russian opposition seems to shift toward the more pro-Kremlin information outlet, which also serves as the digital battleground between pro-Russian and pro-Ukrainian actors. These observations also suggest that the measures employed by the Russian authorities (Kluyeva 2016; Denisova 2017) to cull opposition activities on the Russian blogosphere turned to be effective and limited possibilities for political participation of users critical to the Kremlin politics, while favoring activities of progovernment actors.

Finally, our findings pointed out the presence of distinct clusters of memory content which rarely intersect with each other. This observation suggests that LiveJournal hosts a rather fractured memory system, which puts major focus on state-driven commemoration of the Soviet victory, whereas historical aspects of the war-as well as associated traumatic experiencesremain less visible. While it is hard to draw reliable comparisons with the state of this system before 2014, it seems to be affected by the Ukraine crisis, which led to its growing instrumentalization. We also suggest that the post-2014 changes in media/memory ecosystems led to the shift from discursive conflicts about the interpretation of the past-that is, web memory wars (Rutten, Fedor, and Zvereva 2013) - to the discursive conflicts about the interpretation of the present (i.e., the conflict in Ukraine and the growing confrontation between Russia and the West), where the past serves more as a rhetorical device. At the same time, our analysis indicates that despite its widespread presence, the instrumentalization of Second World War memory constitutes a separate content cluster, which rarely interferes with digital practices of Second World War commemoration.

The latter observation suggests that LiveJournal users seem to differentiate between Second World War remembrance and the instrumental use of war-related memory tropes in the context of the Ukraine crisis. This differentiation can be viewed as evidence that the use of Victory Day as the conceptual framework to interpret the crisis in Ukraine (Siddi 2017) does not necessarily leads to profound changes in Second World War remembrance, which remains a practice in itself. It also poses a question if the use of memory tropes, especially affective characteristics such as "Nazi" or "fascists", does actually rely on cultural memory practices or instead refers to stereotypical negative identities which do not necessarily evoke associations with the Second World War.

Disclosure. Authors have nothing to disclose.

Supplementary Materials. To view supplementary material for this article, please visit http://dx.doi.org/10.1017/nps.2019.64.

Note

1 Our decision to employ LDA is attributed both for it being a state-of-art approach for identifying topics within large text corpora and it being a common approach for qualitative studies on political communication on LiveJournal (Koltsova and Koltcov 2013; Koltsova, Koltcov, and Nikolenko 2016; Nikolenko, Koltcov, and Koltsova 2017) 


\section{References}

Abramov, Roman. 2011. “'Sovetskii cherdak' rossiiskoi blogosfery: analiz nostal'gicheskih virtualnyh soobshestv.” INTER 6: 88-102.

Alexa. 2018. “Top Sites in Russia.” http://www.alexa.com/topsites/countries/RU. (Accessed May 1, 2018.)

Asmolov, Gregory. 2012. "Russia: 11 Areas of Election-Related ICT Innovation.” Global Voices. March 6. https://globalvoices. org/2012/03/06/russia-11-areas-of-election-related-ict-innovation/. (Accessed May 1, 2018.)

Beckhusen, Robert. 2015. "Why Ukrainian Troops Are Calling the Donetsk Airport Siege 'Stalingrad." Medium. January 18. https://medium.com/war-is-boring/why-ukrainian-troops-are-calling-the-donetsk-airport-siege-stalingrad-cef7c4b6a2. (Accessed May 1, 2018.)

Bernhard, Michael, and Jan Kubik. 2014. “A Theory of the Politics of Memory.” In Twenty Years After Communism: The Politics of Memory and Commemoration, edited by Michael Bernhard and Jan Kubik, 7-37. Oxford: Oxford University Press.

Bernstein, Seth. 2016. "Remembering War, Remaining Soviet: Digital Commemoration of World War II in Putin's Russia." Memory Studies 9 (4): 422-436.

Besier, Gerhard, and Katarzyna Stoklosa. 2017. Neighbourhood Perceptions of the Ukraine Crisis: From the Soviet Union Into Eurasia? London: Routledge.

Bodrunova, Svetlana, and Anna Litvinenko. 2013. "New Media and the Political Protest: The Formation of a Public Countersphere in Russia of 2008-12." In Russia's Changing Economic and Political Regimes: Putin Years and Beyond, edited by Andrey Makarychev and Andre Mommen, 29-66. London: Routledge.

Bodrunova, Svetlana, Sergei Koltsov, Olessia Koltsova, Sergey Nikolenko, and Anastasia Shimorina. 2013. "Interval SemiSupervised LDA: Classifying Needles in a Haystack.” In Mexican International Conference on Artificial Intelligence: Advances in Artificial Intelligence and Its Applications, edited by Félix Castro, Alexander Gelbukh, and Miguel González, 265-274. Berlin: Springer.

Denisova, Anastasia. 2017. "Democracy, Protest and Public Sphere in Russia After the 2011-2012 Anti-Government Protests: Digital Media at Stake." Media, Culture \& Society 39 (7): 976-994.

Edele, Mark. 2017. “Fighting Russia’s History Wars: Vladimir Putin and the Codification of World War II." History \& Memory 29 (2): 90-124.

Etling, Bruce, Karina Alexanyan, John Kelly, Robert Faris, John Palfrey and Urs Gasser. 2010. Public Discourse in the Russian Blogosphere: Mapping RuNet Politics and Mobilization. Cambridge: Berkman Center Research.

Fedor, Julie. 2017. "Memory, Kinship, and Mobilization of the Dead: The Russian State and the 'Immortal Regiment' Movement." In War and Memory in Russia, Ukraine and Belarus, edited by Julie Fedor, Markku Kangaspuro, Jussi Lassila, and Tatiana Zhurzhenko, 307-347. London: Palgrave Macmillan.

Frolova, Elena. 2015. “Samye populiarnye sotsial'nye seti v Rossii 2015.” http://www.pro-smm.com/populyarnye-socialnyeseti-v-rossii-2015/. (Accessed March 1, 2019.)

Garde-Hansen, Joanne, Andrew Hoskins, and Anna Reading. 2009. “Introduction.” In Save as...Digital Memories, edited by Joanne Garde-Hansen, Andrew Hoskins, and Anna Reading, 1-27. London: Palgrave Macmillan.

Gaufman, Elizaveta. 2015. "Memory, Media and Securitization: Russian Media Framing of the Ukrainian Crisis." Journal of Soviet and Post-Soviet Politics and Society 1 (1): 141-173.

Gaufman, Elizaveta. 2017. Security Threats and Public Perception. Digital Russia and the Ukraine Crisis. London: Palgrave Macmillan.

Gudkov, Lev. 2005. “'”Pamiat”” o voine i massovaia identichnost' rossiian.” In Pamiat'o voine 60 let spustia: Rossiia, Germaniia, Evropa, edited by Mihail Gabovich, 83-104. Moscow: NLO.

Gruzd, Anatoliy, and Ksenia Tsyganova. 2015. "Information Wars and Online Activism During the 2013/2014 Crisis in Ukraine: Examining the Social Structures of Pro- and Anti-Maidan Groups." Policy \& Internet 7 (2): 121-158.

Khapaeva, Dina. 2016. "Triumphant Memory of the Perpetrators: Putin's Politics of Re-Stalinization." Communist and Post-Communist Studies 49 (1): 61-73.

Khrebtan-Hörhager, Julia. 2016. "Collages of Memory: Remembering the Second World War Differently as the Epistemology of Crafting Cultural Conflicts between Russia and Ukraine." Journal of Intercultural Communication Research 45 (4): 282-303.

Kluyeva, Anna. 2016. "Taming Online Political Engagement in Russia: Disempowered Publics, Empowered State, and Challenges of the Fully Functioning Society." International Journal of Communication 10: 4661-4680.

Kolstø, Pål. 2016. "Symbol of the War - But Which One? The St. George Ribbon in Russian Nation-Building." Slavonic \& East European Review 94 (4): 660-701.

Koltsova, Olessia, and Sergei Koltcov. 2013. "Mapping the Public Agenda with Topic Modeling: The Case of the Russian Livejournal." Policy \& Internet 5 (2): 207-227.

Koltsova, Olessia, and Andrey Shcherbak. 2015. "LiveJournal Libra!': The Political Blogosphere and Voting Preferences in Russia in 2011-2012.” New Media \& Society 17 (10): 1715-1732.

Koltsova, Olessia, Sergei Koltcov, and Sergey Nikolenko. 2016. "Communities of Co-Commenting in the Russian LiveJournal and their Topical Coherence.” Internet Research 26 (3): 710-732.

Koposov, Nikolay. 2017. Memory Laws, Memory Wars: The Politics of the Past in Europe and Russia. Cambridge: Cambridge University Press. 
Kukulin, Ilya. 2013. "Memory and Self-Legitimization in the Russian Blogosphere." In Memory, Conflict and New Media: Web Wars in Post-Socialist States, edited by Ellen Rutten, Julie Fedor, and Vera Zvereva, 112-130. London: Routledge.

Kulyk, Volodymyr. 2013. "War of Memories in the Ukrainian Media: Diversity of Identities, Political Confrontation, and Production Technologies." In Memory, Conflict and New Media: Web Wars in Post-Socialist States, edited by Ellen Rutten, Julie Fedor, and Vera Zvereva, 63-81. London: Routledge.

Kuntsman, Adi. 2010. "Webs of Hate in Diasporic Cyberspaces: The Gaza War in the Russian-Language Blogosphere." Media, War \& Conflict 3 (3): 299-313.

Kupfer, Matthew and Thomas de Waal. 2014. "Crying Genocide: Use and Abuse of Political Rhetoric in Russia and Ukraine." Carnegie Endowment for International Peace. http://carnegieendowment.org/2014/07/28/crying-genocide-use-and-abuse-ofpolitical-rhetoric-in-russia-and-ukraine. (Accessed March 1, 2019.)

Makhortykh, Mykola. 2018. “\#NoKievNazi: Social Media, Historical Memory and Securitization in the Ukraine Crisis.” In Memory and Securitization in Contemporary Europe, edited by Vlad Strukov and Viktor Apryshchenko, 219-249. London: Palgrave Macmillan.

Makhortykh, Mykola and Yehor Lyebyedyev. 2015. “\#SaveDonbassPeople: Twitter, Propaganda, and Conflict in Eastern Ukraine.” The Communication Review 18 (4): 239-270.

Malinova, Olga. 2017. "Political Uses of the Great Patriotic War in Post-Soviet Russia from Yeltsin to Putin." In War and Memory in Russia, Ukraine and Belarus, edited by Julie Fedor, Markku Kangaspuro, Jussi Lassila, and Tatiana Zhurzhenko, 43-71. London: Palgrave Macmillan.

Mejias, Ulises, and Nikolai Vokuev. 2017. “Disinformation and the Media: The Case of Russia and Ukraine." Media, Culture \& Society 39 (7): 1027-1042.

Morenkova, Elena. 2012. "(Re)creating the Soviet Past in Russian Digital Communities. Between Memory and Mythmaking." Digital Icons: Studies in Russian, Eurasian and Central European New Media 7: 39-66.

Nikolenko, Sergey I., Sergei Koltcov, and Olessia Koltsova. 2017. “Topic Modelling for Qualitative Studies.” Journal of Information Science 43 (1): 88-102.

Petro, Nicolai. 2017. Ukraine in Crisis. London and New York: Routledge.

Overy, Richard. 1998. Russia's War. London: Penguin Books.

Roudakova, Natalia. 2017. Losing Pravda: Ethics and the Press in Post-Truth Russia. Cambridge: Cambridge University Press.

Rutten, Ellen, and Vera Zvereva. 2013. “Introduction: Old Conflicts, New Media: Post-Socialist Digital Memories.” In Memory, Conflict and New Media: Web Wars in Post-Socialist States, edited by Ellen Rutten, Julie Fedor, and Vera Zvereva, 1-19. London: Routledge.

Rutten, Ellen, Julie Fedor, and Vera Zvereva. 2013. Memory, Conflict and New Media: Web Wars in Post-Socialist States. London: Routledge.

Sakwa, Richard. 2014. Frontline Ukraine: Crisis in the Borderlands. London: I.B.Tauris.

Sazonov, Vladimir, Kristiina Müür, and Mölder Holger. 2016. Russian Information Campaign Against the Ukrainian State and Defence Forces. Riga: NATO Strategic Communications Centre of Excellence.

Siddi, Marco. 2017. “The Ukraine Crisis and European Memory Politics of the Second World War." European Politics and Society 18 (4): 465-479.

Suslov, Mikhail. 2014. “'Crimea is Ours!' Russian Popular Geopolitics in the New Media Age.” Eurasian Geography and Economics 55 (6): 588-609.

Tofler, Alvin. 1980. The Third Wave. New York: William Morrow.

Tumarkin, Nina. 1994. The Living and the Dead: The Rise and Fall of the Cult of World War II in Russia. New York: Basic Books.

Trubina, Elena. 2010. "Past Wars in the Russian Blogosphere: On the Emergence of Cosmopolitan Memory." Digital Icons: Studies in Russian, Eurasian and Central European New Media 4: 63-85.

Wilson, Andrew. 2014. Ukraine Crisis: What it Means for the West. New Haven, CT: Yale University Press.

Yandex. 2006. "Blogosfera rossiiskogo interneta." https://web.archive.org/web/20061116162903/http://company.yandex.ru/ articles/yandex_on_blogosphere_autumn_2006.pdf. (Accessed May 1, 2018.)

Zhdanova, Mariia, and Daria Orlova. 2017. "Computational Propaganda in Ukraine: Caught Between External Threats and Internal Challenges.” http://comprop.oii.ox.ac.uk/wp-content/uploads/sites/89/2017/06/Comprop-Ukraine.pdf. (Accessed May 1, 2018.)

Zvereva, Vera. 2011. “Diskussii o sovetskom proshlom v soobshestvah seti 'V Kontakte.” Vestnik obshestvennogo mnenia 110 (4): $97-112$

Cite this article: Makhortykh, M. Lyebyedyev, Y., and Kravtsov, D. 2021. Past Is Another Resource: Remembering the 70th Anniversary of the Victory Day on LiveJournal. Nationalities Papers 49: 375-388, doi:10.1017/nps.2019.64 